\title{
Evaluation of Morphometric Traits of Kashmir Merino Sheep under Field and Farm Conditions
}

\author{
Qysheed Hussain Want ${ }^{1 *}$, M. T. Banday ${ }^{2}$, S. Adil ${ }^{2}$, H. M. Khan ${ }^{2}$ and A. A. Khan ${ }^{2}$ \\ ${ }^{1}$ Sheep Development Officer, Sheep Husbandry Department, Kashmir, India \\ ${ }^{2}$ Division of Livestock Production and Management Faculty of Veterinary Sciences and \\ Animal Husbandry, Shuhama, SKUAST-K, Kashmir, India \\ *Corresponding author
}

\begin{tabular}{|c|}
\hline Keywords \\
\hline $\begin{array}{l}\text { Kashmir Merino, } \\
\text { Morphometric } \\
\text { traits, J\&K, } \\
\text { Improvement, } \\
\text { Selection }\end{array}$ \\
\hline Article Info \\
\hline $\begin{array}{l}\text { Accepted: } \\
\text { 18 July } 2020 \\
\text { Available Online: } \\
10 \text { August } 2020\end{array}$ \\
\hline
\end{tabular}

\section{A B S T R A C T}

Kashmir Merino sheep are used by the rural farmers as a source of food and cash and are believed to have adapted to harsh conditions of Kashmir region. There is scanty information available about the characteristics of this breed. The aim of this study was to characterise this breed on the basis of morphometric traits for the purposes of its conservation. A study was conducted in four community development blocks of district Srinagar and Sheep Breeding Farm Dachigam in the union territory of Jammu \& Kashmir under farm and field conditions utilizing 897 sheep. Present study revealed that Kashmir Merino sheep is off-white in colour predominantly with narrow long and convex head profile (45.2\%); ears are predominantly broad and droopy (42.2\%) and horns oriented in backward forward \& outward direction $(80.9 \%)$ although majority $(78.5 \%)$ of the animals were polled. In conclusion, the phenotypic diverseness in Kashmir Merino sheep provides an opportunity to exploit this sheep by selecting animals related to phenotypic features.

\section{Introduction}

About $73 \%$ of rural India owns livestock and this sector provides employment to 22.45 million people directly or indirectly. The livestock sector alone contributes nearly $25.6 \%$ of Value of output at current prices of total value of output in Agriculture, Fishing \& Forestry sector. The overall contribution of
Livestock Sector in total GDP is nearly $4.11 \%$ at current prices during 2012-13 (Anonymous, 2012). The J\&K is ideally suited for rearing of sheep and goats owing to its favourable agro climatic conditions, rich alpine pastures and host of other natural endowments. Sheep and goat rearing is the core activity of rural masses in $\mathrm{J} \& \mathrm{~K}$ and plays a vital role in socioeconomic upliftment of 
weaker sections of the society viz, Gujjars \& Bakarwalls, Chopans, Gaddies and Changpas. The $\mathrm{J} \& \mathrm{~K}$ is native to about 9.2 million livestock excluding poultry with a population of 5.4 million small ruminants representing approximately $59 \%$ sheep alone (3.389 million) representing approximately $37 \%$ of the total livestock population of the state (Anonymous, 2012).

Kashmir Merino is a crossbred strain developed by crossing Gaddi, Bhakarwal and Poonchi with 50 to $75 \%$ exotic inheritance of Rambouillet and Merino sheep in J\&K (Tomar, 2004). It was a huge success in terms of improving the wool and mutton production. In spite of being such a success there is barely any documentation about its morphometric characteristics. Also, the growth performance of this sheep over the years has declined which needs effective development programmes for redressal, therefore, the present study was undertaken.

\section{Materials and Methods}

The proposed work was undertaken in the four community development (CD) blocks of district Srinagar and Sheep Breeding Farm Dachigam where the Kashmir Merino breed was evolved. Srinagar city is located at an average elevation of 1600 meters above mean sea level and it is spread over in the heart of the oval shaped Valley of Kashmir. It is situated between 740-56' and 750-79' East Longitude and 330-18' and 340-45' North Latitude. Srinagar has a humid subtropical climate, much cooler than what is found in much of the rest of India, due to its moderately high elevation and northerly position. The valley is surrounded by the Himalayas on all sides (Anonymous, 2015a).

The following morphometric parameters were collected with the help of a measuring tape from 897 animals from selected areas and
Sheep Breeding Farm Dachigam:

Head length: Measured from point of poll up to the tip of upper lip and expressed in centimetres.

Ear length: Measured from the base of ear to the tip of pinna and expressed in centimetres.

Horn length: Measured from base to the tip of horn and expressed in centimetres.

Chest girth: Measured by passing the measuring tape around the chest immediate behind the point of elbow and expressed in centimetres

Height at withers: Measured up to the point of withers from the ground when the animal stood straight on all its four legs and expressed in centimetres.

Tail length: Measured as distance from the base (sacro-coccygeal articulation) to the tip of tail. The size of the tail was expressed in centimetres.

Body length: Measured as length from point of shoulder to the point of pin bone and expressed in centimetres

\section{Data entry and analysis}

The statistical analysis was done as per Snedecor and Cochran (1994) using Statistical Package for Social Sciences (SPSS-20) computer programme and results expressed as (Mean $\pm \mathrm{SE}$ ). The means were considered significant at $\mathrm{p}<0.05$.

\section{Results and Discussion}

\section{Head length}

The mean head length $(\mathrm{cm})$ among the sheep from field and farm at different age groups 
has been presented in Table 1 . The mean head length in males was significantly $(\mathrm{P}>0.05)$ higher in sheep reared under field conditions at temporary tooth and 8-tooth age group where as it was higher in sheep reared under farm conditions at 6-tooth stage. Male sheep with 2-tooth (hogget) were not available in the farm whereas those with broken mouth were not available in either of the group. In other age groups (4-tooth \& 6-tooth) the difference was statistically insignificant. The head length was found statistically insignificant $(\mathrm{P}>0.05)$ in all the age groups among female sheep of field and farm. However, the female sheep from farm had significantly $(\mathrm{p}<0.05)$ higher head length than field among the temporary-teeth group of animals. However, earlier Pervage et al., (2009) reported higher head length in males than females in indigenous sheep of Jamuna region of Bangladesh.

\section{Horn length}

The mean horn length $(\mathrm{cm})$ among the sheep from field and farm at different age groups has been presented in Table 2. Since majority (91.91) of the female sheep were polled and any horned female found in the farm was mostly culled hence few horned females were available for data collection. Among the male sheep majority were horned $(75.75 \%)$, the horn length was observed to be significantly $(\mathrm{p}<0.05)$ higher in the male sheep from farm at temporary teeth \& 4-tooth age group when compared to male sheep from the field whereas it was found higher in the males from field than farm at the age of 6-tooth. Among the females the horn length was significantly $(p<0.05)$ more in the farm reared animals than field among the 6-tooth age group of animals whereas female sheep from field had significantly $(\mathrm{p}<0.05)$ longer horn length than farm among 8-tooth age group of animals. No particular trend in the length of horn under field and farm conditions was observed both in males and females. In male group highest horn length of $65.19 \mathrm{~cm}$ was recorded from the field whereas $60.96 \mathrm{~cm}$ of horn length was recorded from the farm. Kashmir Merino breed is known for long curved horns. These results corroborate with earlier reports of Arora et al., (2010) who recorded higher horn lengths $20.9 \pm 1.5 \mathrm{~cm}$ in Ganjam sheep. However, lower horn lengths $7.50 \pm 1.80 \mathrm{~cm}$ was measured by Pervage et al., (2009) in indigenous sheep of Bangladesh.

\section{Ear length}

The mean ear length $(\mathrm{cm})$ among the sheep from field and farm at different age groups has been presented in Table 3. No significant $(p<0.05)$ difference was observed in ear lengths in the male sheep except at 6-tooth \& 8 -tooth stage where it was significantly $(p<0.05)$ higher in field when compared with animals from farm. Similarly females under field and farm conditions showed no significant $(\mathrm{p}<0.05)$ difference except at temporary-teeth stage where length of ears was significantly $(\mathrm{p}<0.05)$ higher in farm when compared with those of field. The results are in line with the reports of Tariq et al., (2011) who reported no significant difference in ear length between farmers flock and experimental station flock. Similarly no significant difference $(\mathrm{P}>0.05)$ was reported between male and female ear length by Pervage et al., (2009), Ganai et al., (2010) and Ganai et al., (2011) in indigenous sheep of Bangladesh, Changthangi sheep and Gurez sheep, respectively. Higher ear lengths were reported earlier in Jaiselmeri sheep and Hissardale sheep by a number of workers (Arora et al., 2007; Younas et al., 2013), respectively.

\section{Wither height}

The wither height $(\mathrm{cm})$ among the sheep from field and farm at different age groups has been presented in Table 4. Among male group no significant $(\mathrm{p}<0.05)$ difference was 
observed in wither height except at temporary-teeth where it was significantly $(p<0.05)$ higher in field reared animals when compared to farm reared animals. However, significantly $(p<0.05)$ higher wither height was observed in the female sheep from field at 2-tooth, 4-tooth, 6-tooth \& 8-tooth stage of animals when compared with same group of female sheep reared in farm. These results are in contrary to the findings of Tariq et al., (2011) who reported higher height at wither in the farmers flock. The height at wither of Kashmir Merino sheep is comparable to Zulu, Pugal, Gurez, indigenous sheep of Bangladesh and Ganjam sheep (Kunene et al., 2007; Dass. 2008; Ganai et al., 2010; Arora et $a l ., 2010)$. These findings are within the range of the reports of Gupta (1994) for different local breeds in which height at withers of Gaddie, Bakerwal, Poonchi, Karnah, Gurezi and Valley sheep was observed to be $56.6 \mathrm{~cm}$, $62.0 \mathrm{~cm}, 57.0 \pm 1.89 \mathrm{~cm}, 70.0 \mathrm{~cm}, 71.2 \mathrm{~cm}$ and $50.0 \mathrm{~cm}$ respectively.

\section{Chest girth}

The chest girth (cm) among the sheep from field and farm at different age groups has been presented in Table 5. No significant $(p<0.05)$ difference was observed in male group between field and farm reared animals among all age groups. At 2-tooth and broken mouth stage no comparison could be made under the male category due to nonavailability of animals in this group. In female group chest girth was significantly $(\mathrm{p}<0.05)$ higher in field than farm at 4-tooth \& 8-tooth whereas at temporary-teeth stage it was significantly $(p<0.05)$ higher in farm reared sheep than field reared sheep. These results are in line with the earlier reports of Zubair (2013) who reported that chest girth under field conditions was significantly $(p<0.05)$ higher than chest girth under farm conditions in Bakerwal goats. However, Tariq et al.,
(2011) reported higher girth of chest in experimental station flock than farmers flock. In contrary chest girth of Zulu, Pugal, indigenous sheep of Bangladesh, Gurez, and Ganjam sheep was estimated to be lower than present findings by (Kunene et al., 2007; Dass, 2008; Pervage et al., 2009; Ganai et al., 2010; Arora et al., 2010) respectively. The present findings are in line with the reports of Gupta (1994) who reported the height at withers of Gaddie, Bakerwal, Poonchi, Karnah, Gurezi and Valley sheep to be $74.4 \mathrm{~cm}, 82.0 \mathrm{~cm}, 72.0 \pm 2.63 \mathrm{~cm}, 92.1 \mathrm{~cm}$, $100.0 \mathrm{~cm}$ and $70.0 \mathrm{~cm}$ respectively.

\section{Body length}

The mean body length $(\mathrm{cm})$ among the sheep from field and farm at different age groups has been presented in Table 6. No significant $(\mathrm{p}<0.05)$ difference was observed in male group between field and farm reared sheep except at temporary-teeth \& 8-tooth stage where it was more in the farm than field reared sheep among the same group of animals. Similarly, no significant difference was observed in female group under field and farm conditions except at temporary-teeth stage where it is significantly higher $(\mathrm{p}<0.05)$ in farm than field reared sheep among the same group of animals. These results are in line with the reports of Tariq et al., (2011) who reported that body length of experimental station flock was higher than farmers flock. In contrary to present findings, Zubair (2013) reported significantly $(\mathrm{p}<0.05)$ higher body length in Bakarwal goats under field conditions than body length under farm conditions whereas present findings were within the range of body lengths reported in Gurez sheep, indigenous sheep of Bangladesh and Ganjam sheep by Ganai et al., (2010), Pervage et al., (2009) and Arora et al., (2010) respectively. 
Table.1 Head length $(\mathrm{cm})$ of Kashmir Merino sheep at different age groups

\begin{tabular}{|l|l|l|l|}
\hline Age group & Sex & Field $(M e a n \pm S E)$ & Farm $(M e a n \pm$ SE) \\
\hline Temporary teeth & Male & $19.40^{\mathrm{a}} \pm 0.18(63)^{*}$ & $18.91^{\mathrm{b}} \pm 0.15(51)$ \\
& Female & $18.55^{\mathrm{a}} \pm 0.15(86)$ & $19.28^{\mathrm{b}} \pm 0.14(32)$ \\
\hline Two Tooth & Male & $21.41 \pm 0.35(19)$ & N/A \\
& Female & $19.83 \pm 0.14(93)$ & $20.37 \pm 0.16(19)$ \\
\hline Four tooth & Male & $23.15 \pm 0.78(7)$ & $22.04 \pm 0.46(5)$ \\
\hline Six tooth & Female & $20.94 \pm 0.18(60)$ & $20.71 \pm 0.13(39)$ \\
\hline Eight tooth & Male & $22.60^{\mathrm{a}} \pm 0.76(7)$ & $23.53^{\mathrm{b}} \pm 0.36(3)$ \\
& Female & $20.97 \pm 0.14(78)$ & $21.10 \pm 0.16(39)$ \\
\hline Broken mouth & Male & $25.06^{\mathrm{a}} \pm 0.29(6)$ & $22.22^{\mathrm{b}} \pm 0.52(4)$ \\
& Female & $21.47 \pm 0.15(128)$ & $21.30 \pm 0.09(125)$ \\
\hline & Female & N/A & N/A \\
\hline
\end{tabular}

Means with different superscripts in a row differ significantly from each other $(\mathrm{p}<0.05)$

* Figures in parenthesis indicate number of animals

N/A = Not Available

Table.2 Horn length $(\mathrm{cm})$ of Kashmir Merino sheep at different age groups

\begin{tabular}{|l|l|l|l|}
\hline \multicolumn{1}{|c|}{ Age group } & \multicolumn{1}{|c|}{ Sex } & Field $($ Mean \pm SE) & \multicolumn{1}{|c|}{ Farm $($ Mean \pm SE) } \\
\hline Temporary teeth & $\begin{array}{l}\text { Male } \\
\text { Female }\end{array}$ & $\begin{array}{l}23.19^{\mathrm{a}} \pm 0.89(63)^{*} \\
17.35 \pm 1.58(9)\end{array}$ & $\begin{array}{l}26.67^{\mathrm{b}} \pm 1.28(35) \\
\text { N/A }\end{array}$ \\
\hline Two Tooth & Male & $33.21 \pm 2.89(16)$ & N/A \\
& Female & $21.86 \pm 1.73(11)$ & N/A \\
\hline Four tooth & Male & $40.64^{\mathrm{a}} \pm 4.17(7)$ & $51.05^{\mathrm{b}} \pm 3.55(2)$ \\
& Female & $21.52 \pm 1.80(4)$ & N/A \\
\hline Six tooth & Male & $65.19^{\mathrm{a}} \pm 2.84(3)$ & $60.96^{\mathrm{b}} \pm----^{(1)}$ \\
& Female & $19.30^{\mathrm{a}} \pm 3.55(2)$ & $24.63^{\mathrm{b}} \pm----(1)$ \\
\hline Eight tooth & Male & $48.07 \pm 8.40(6)$ & $50.80 \pm 3.81(2)$ \\
& Female & $26.25^{\mathrm{a}} \pm 3.83(14)$ & $14.92^{\mathrm{b}} \pm 2.45(4)$ \\
\hline Broken mouth & Male & N/A & N/A \\
& Female & $28.70 \pm 11.93(2)$ & N/A \\
\hline
\end{tabular}

Means with different superscripts in a row differ significantly from each other $(\mathrm{p}<0.05)$

* Figures in parenthesis indicate number of animals 
Table.3 Ear length $(\mathrm{cm})$ of Kashmir Merino sheep at different age groups

\begin{tabular}{|l|l|l|l|}
\hline \multicolumn{1}{|c|}{ Age group } & \multicolumn{1}{|c|}{ Sex } & \multicolumn{1}{c|}{ Field $($ Mean \pm SE) } & \multicolumn{1}{c|}{ Farm $($ Mean \pm SE) } \\
\hline Temporary teeth & Male & $11.97 \pm 0.14(78)^{*}$ & $11.73 \pm 0.17(51)$ \\
& Female & $11.87^{\mathrm{a}} \pm 0.17(86)$ & $12.13^{\mathrm{b}} \pm 0.15(32)$ \\
\hline Two-Tooth & Male & $11.44 \pm 0.39(19)$ & N/A \\
& Female & $11.52 \pm 0.26(93)$ & $11.81 \pm 0.24(19)$ \\
\hline Four-Tooth & Male & $7.80 \pm 2.09(7)$ & $11.98 \pm 0.47(5)$ \\
\hline Six-Tooth & Female & $12.09 \pm 0.21(60)$ & $11.89 \pm 0.20(39)$ \\
\hline Eight-Tooth & Male & $11.68^{\mathrm{a}} \pm 0.47(7)$ & $11.76^{\mathrm{b}} \pm 0.93(3)$ \\
& Female & $11.82 \pm 0.26(78)$ & $11.82 \pm 0.15(39)$ \\
\hline Broken mouth & Female & $12.10^{\mathrm{a}} \pm 0.46(6)$ & $11.43^{\mathrm{b}} \pm 0.74(4)$ \\
& Male & N/A $\pm 0.19(128)$ & $11.69 \pm 0.10(125)$ \\
\hline
\end{tabular}

Means with different superscripts in a row differ significantly from each other $(p<0.05)$

* Figures in parenthesis indicate number of animals

Table.4 Wither Height $(\mathrm{cm})$ of Kashmir Merino sheep at different age groups

\begin{tabular}{|l|l|l|l|}
\hline \multicolumn{1}{|c|}{ Age group } & \multicolumn{1}{|c|}{ Sex } & \multicolumn{1}{c|}{ Field $($ Mean \pm SE) } & \multicolumn{1}{c|}{ Farm $($ Mean \pm SE) } \\
\hline Temporary teeth & Male & $57.76^{\mathrm{a}} \pm 0.46(78)^{*}$ & $55.98^{\mathrm{b}} \pm 0.38(51)$ \\
& Female & $56.09 \pm 0.58(86)$ & $56.56 \pm 0.42(32)$ \\
\hline Two Tooth & Male & $65.25 \pm 1.76(19)$ & N/A \\
& Female & $61.26^{\mathrm{a}} \pm 0.52(93)$ & $58.23^{\mathrm{b}} \pm 0.71(19)$ \\
\hline Four Tooth & Male & $68.58 \pm 0.81(7)$ & $64.26 \pm 1.23(5)$ \\
\hline Six Tooth & Female & $62.44^{\mathrm{a}} \pm 0.51(60)$ & $59.11^{\mathrm{b}} \pm 0.42(39)$ \\
\hline Eight Tooth & Male & $66.98 \pm 2.69(7)$ & $69.68 \pm 2.58(3)$ \\
& Female & $62.19^{\mathrm{a}} \pm 0.62(78)$ & $59.61^{\mathrm{b}} \pm 0.60(39)$ \\
\hline Broken mouth & Female & $68.36 \pm 2.54(6)$ & $66.86 \pm 1.80(4)$ \\
& Male & N/A $2^{\mathrm{a}} \pm 0.42(128)$ & $60.62^{\mathrm{b}} \pm 0.31(125)$ \\
\hline
\end{tabular}

Means with different superscripts in a row differ significantly from each other $(\mathrm{p}<0.05)$

* Figures in parenthesis indicate number of animals 
Table.5 Chest Girth $(\mathrm{cm})$ of Kashmir Merino sheep at different age groups

\begin{tabular}{|l|l|l|l|}
\hline \multicolumn{1}{|c|}{ Age group } & \multicolumn{1}{|c|}{ Sex } & \multicolumn{1}{c|}{ Field $(M e a n \pm$ SE) } & \multicolumn{1}{c|}{ Farm $($ Mean \pm SE) } \\
\hline Temporary teeth & Male & $71.43 \pm 0.58(78)^{*}$ & $71.33 \pm 0.61(51)$ \\
& Female & $71.64^{\mathrm{a}} \pm 0.56(86)$ & $75.00^{\mathrm{b}} \pm 0.62(32)$ \\
\hline Two Tooth & Male & $77.22 \pm 1.39(19)$ & N/A \\
& Female & $79.07 \pm 0.55(93)$ & $79.31 \pm 1.36(19)$ \\
\hline Four tooth & Male & $86.97 \pm 2.21(7)$ & $88.84 \pm 1.46(5)$ \\
& Female & $81.82^{\mathrm{a}} \pm 0.76(60)$ & $78.68^{\mathrm{b}} \pm 0.79(39)$ \\
\hline Six tooth & Male & $89.04 \pm 3.38(7)$ & $94.23 \pm 1.39(3)$ \\
\hline Eight tooth & Female & $83.03 \pm 0.76(78)$ & $80.81 \pm 0.76(39)$ \\
\hline Broken mouth & Male & $93.64 \pm 2.33(6)$ & $96.71 \pm 3.60(4)$ \\
& Female & $87.15^{\mathrm{a}} \pm 0.73(128)$ & $82.45^{\mathrm{b}} \pm 0.53(125)$ \\
\hline & Female & N/A & N/A \\
\hline
\end{tabular}

Means with different superscripts in a row differ significantly from each other $(\mathrm{p}<0.05)$

* Figures in parenthesis indicate number of animals

Table.6 Body Length $(\mathrm{cm})$ of Kashmir Merino sheep at different age groups

\begin{tabular}{|l|l|l|l|}
\hline \multicolumn{1}{|c|}{ Age group } & \multicolumn{1}{|c|}{ Sex } & \multicolumn{1}{c|}{ Field $(M e a n \pm$ SE) } & \multicolumn{1}{c|}{ Farm $(M e a n \pm$ SE) } \\
\hline Temporary teeth & Male & $57.30^{\mathrm{a}} \pm 0.48(78)^{*}$ & $59.66^{\mathrm{b}} \pm 0.59(51)$ \\
& Female & $57.72^{\mathrm{a}} \pm 0.52(86)$ & $61.30^{\mathrm{b}} \pm 0.80(32)$ \\
\hline Two Tooth & Male & $61.86 \pm 1.27(19)$ & N/A \\
& Female & $62.00 \pm 0.50(93)$ & $63.83 \pm 0.77(19)$ \\
\hline Four tooth & Male & $67.89 \pm 1.91(7)$ & $70.35 \pm 1.39(5)$ \\
\hline Six tooth & Female & $64.51 \pm 0.68(60)$ & $62.97 \pm 0.62(39)$ \\
\hline Eight tooth & Male & $70.21 \pm 2.62(7)$ & $74.42 \pm 1.87(3)$ \\
& Female & $65.53 \pm 0.54(78)$ & $64.13 \pm 0.61(39)$ \\
\hline Broken mouth & Male & $69.59^{\mathrm{a}} \pm 2.93(6)$ & $80.45^{\mathrm{b}} \pm 1.96(4)$ \\
& Female & $65.96 \pm 0.39(128)$ & $65.01 \pm 0.32(125)$ \\
\hline & Female & N/A & N/A \\
& $66.81 \pm 0.75(16)$ & $66.29 \pm 3.81(2)$ \\
\hline
\end{tabular}

Means with different superscripts in a row differ significantly from each other $(\mathrm{p}<0.05)$

* Figures in parenthesis indicate number of animals 
Table.7 Tail Length $(\mathrm{cm})$ of Kashmir Merino sheep at different age groups

\begin{tabular}{|l|l|l|l|}
\hline \multicolumn{1}{|c|}{ Age group } & \multicolumn{1}{c|}{ Sex } & \multicolumn{1}{c|}{ Field $(M e a n \pm$ SE) } & \multicolumn{1}{c|}{ Farm $(M e a n \pm$ SE) } \\
\hline Temporary teeth & Male & $32.33 \pm 0.65(76)^{*}$ & N/A \\
& Female & $31.45^{\mathrm{a}} \pm 0.49(85)$ & $35.89^{\mathrm{b}} \pm 0.51(3)$ \\
\hline Two Tooth & Male & $31.28 \pm 1.22(19)$ & N/A \\
& Female & $32.43^{\mathrm{a}} \pm 0.48(92)$ & $35.94^{\mathrm{b}} \pm 2.66(2)$ \\
\hline \multirow{2}{*}{ Four tooth } & Male & $37.22 \pm 1.78(7)$ & N/A \\
& Female & $32.54 \pm 0.68(59)$ & $33.02 \pm---(1)$ \\
\hline Six tooth & Male & $39.07 \pm 2.61(7)$ & $41.91 \pm---(1)$ \\
& Female & $32.69^{\mathrm{a}} \pm 0.54(78)$ & $36.19^{\mathrm{b}} \pm 1.90(2)$ \\
\hline Eight tooth & Male & $38.95 \pm 2.52(5)$ & $38.94 \pm 1.12(3)$ \\
& Female & $31.77^{\mathrm{a}} \pm 0.44(128)$ & $34.86^{\mathrm{b}} \pm 2.89(4)$ \\
\hline Broken mouth & Male & N/A & N/A \\
& Female & $28.63 \pm 1.31(16)$ & N/A \\
\hline
\end{tabular}

Means with different superscripts in a row differ significantly from each other $(\mathrm{p}<0.05)$

* Figures in parenthesis indicate number of animals

Similarly, these findings are within or over the range of reports of Gupta (1994) that height at withers of different local breeds like Gaddie, Bakerwal, Poonchi, Karnah, Gurezi and Valley sheep were $55.5 \mathrm{~cm}, 65.0 \mathrm{~cm}$, $56.7 \pm 1.97 \mathrm{~cm}, 72.0 \mathrm{~cm}, 71.0 \mathrm{~cm}$ and $53.0 \mathrm{~cm}$ respectively.

\section{Tail length}

The mean tail length $(\mathrm{cm})$ among the sheep from field and farm at different age groups has been presented in Table 7. Among the different sexes female from farm had significantly $(\mathrm{p}<0.05)$ longer tail length when compared with the tail length of female sheep from field among temporary-teeth, 2-tooth, 6tooth \& 8-tooth age group. In farm, as a routine managemental practice, male sheep are docked at early age hence no comparison between field and farm could be drawn within this group. Tariq et al., (2011) reported higher tail length in experimental station flock than tail length of farmers flock. Lower tail length was reported by a number of workers Arora $e t$ al., (2010); Handiwirawn et al., (2011) and Younas et al., (2013) in Ganjam sheep, Garut loval and Hissardale sheep respectively.
In conclusion, the phenotypic diverseness in Kashmir Merino sheep provides an opportunity to exploit this sheep by selecting animals related to phenotypic features.

\section{References}

Anonymous (2012) $19^{\text {th }}$ Livestock census-all India report. Govt. of India, Directorate of Economics \& Statistics. Ministry of Agriculture, department of Animal Husbandry, Dairying and Fisheries Krishi Bhawan, New Delhi.

Anonymous (2015a) Extremes of India. http//www.indpune.gov.in. Retrieved 11 January 2015.

Arora, A.L., Prince L.L.L. and Mishra, A.K. (2007) Performance evaluation of Jaisalmeri sheep in farmer's flocks. Ind. J. Anim. Sci., 77(8): 759-762.

Arora, R., Bhatia, S. and Jain, A. (2010) Morphological and genetic characterization of Ganjamsheep. Anim. Gen. Res., 4(6): 1-9.

Dass, G., Prasad, H., Mandal, A., Singh, M. K. and N, P. (2008) Growth characters of Muzaffarnagri sheep under semi intensive feeding management. Ind. J. 
Anim. Sci., 78(9): 1032-1033.

Ganai, T.A.S., Misra, S.S. and Sheikh, F.D. (2010) Gurez a threatened sheep breed of Kashmir. Ind. J. Anim. Sci., 80(8): 806-808.

Ganai, T.A.S., Misra, S.S. and Sheikh, F.D. (2011) Description of Changthangi sheep of Ladakh. Indian Journal of Small Ruminants 17(1): 32-40.

Gupta, J.L. (1994) Sheep Development In Temperate Region, First Edition, 54-57, CBS Publishers and Distributors, New Delhi.

Handiwirawan, D., Noor, R.R., Sumantri, C. and Ubandriyo. (2011) The differentiation of sheep breed based on body measurements. J. Indon. Trop. Anim. Agric., 36(1): 1-8

Kunene, N.W., Nesamvuni, E.A., Fossey, A. (2007) Characterization of Zulu (Nguni) sheep using linear body measurements and some environmental factors affecting these measurements. South Afr. J. Anim. Sci., 37(1): 11-20

Pervage, S., Ershaduzzaman, M., Talukder, I.A.M., Hasan, N.M. and Khandoker, M.A.M.Y. (2009) Phenotypic Charecterization of indeginous sheep of Bangladesh. Bang. J. Anim. Sci.
38(1\&2): 1-6.

Snedecor, G.W. and Cochran, W.G. (19940 Statistical Methods. 6th Edn. Iowa State University Press. Ames, Iowa.

Tariq, M.M., Bajwa, M.A., Abbas, F., Eyduran, E., Awan, M.A., Rafeeq, M., Waheed, A., Husssain, A., Bukhari, F.A., Attiq M.A., Ahmad, Z. and Javid, Y. (2011) Some Morphological, Fertility and Growth Traits for Mengali Sheep of Balochistan, Pakistan. I $\breve{g} d \imath r$ Univ. J. Inst. Sci. Tech., 1(1): 63-68.

Tomar, S.S (2004) Textbook of Animal Breeding. Kalyani Publishers, Ludhiana.

Younas, U., Abdullah, M., Bhatti, J.A., Pasha, T.N., Ahmad, N., Nasir, M. and Hussain, A. (2013) Inter-relationship of body weight with linear body measurements in Hissardale sheep at different stages of life. J. Anim. Plant Sci., 23(1): 40-44.

Zubair, A. (2013) Morphometric and Performance Traits of Bakarwal goats. M.V.Sc Thesis submitted to Sher-eKashmir University of agricultural Sciences and Technology, Kashmir.

\section{How to cite this article:}

Qysheed Hussain Want, M. T. Banday, S. Adil, H. M. Khan and Khan, A. A. 2020. Evaluation of Morphometric Traits of Kashmir Merino Sheep under Field and Farm Conditions. Int.J.Curr.Microbiol.App.Sci. 9(08): 1632-1640. doi: https://doi.org/10.20546/ijcmas.2020.908.187 